\title{
Synthesis, spectroscopy, photophysics and thermal behaviour of stilbene-based triarylamines with dehydroabietic acid methyl ester moieties $\dagger$
}

\author{
Bárbara Gigante, ${ }^{a} a$ M. Alexandra Esteves, ${ }^{a}$ N. Pires, ${ }^{a}$ Matthew L. Davies,${ }^{b c}$ \\ Peter Douglas, ${ }^{b}$ Sofia M. Fonseca, ${ }^{c}$ Hugh D. Burrows, ${ }^{c}$ Ricardo A. E. Castro, ${ }^{d}$ \\ João Pina ${ }^{c}$ and João Seixas de Melo ${ }^{c}$
}

Received (in Durham, UK) 9th September 2008, Accepted 14th January 2009

First published as an Advance Article on the web 5th February 2009

DOI: $10.1039 / \mathbf{b 8 1 5 7 1 1 a}$

Novel stilbene-based triarylamines with dehydroabietic acid methyl ester moieties have been synthesised by palladium catalysed $\mathrm{C}-\mathrm{N}$ coupling reactions. The presence of the bulky dehydroabietic acid group increases solubility, hinders crystallisation and permits their sublimation while preserving their electronic and optical characteristics. This makes them good candidates for various molecular electronic applications. We report a detailed characterisation of their electrochemical, spectroscopic and photophysical properties. In addition, the thermal stability and behaviour is discussed with reference to the potential for preparation of stable thin films.

\section{Introduction}

To achieve organic materials offering high performance for various molecular electronic applications, including organic light-emitting diodes (OLEDs), photovoltaic systems and non-linear optics, intensive research has been focused on the development of new compounds with significant improvements in non-crystallinity or amorphous film-forming ability, thermal stability, electrochemical reversibility, emission colour purity and lifetime. These have been accompanied by advances in device architecture, leading to tremendous progress in the design and synthetic strategies. ${ }^{1}$

For photovoltaic and LED applications, optimisation of the charge carrier separation or balance using multilayer structures is a common method to improve efficiency. Hole-transporting layers (HTL), which may also act as electron-blocking layers, have been widely used for this. Triarylamines offer particularly attractive properties as HTL, such as high hole mobility and ease of sublimation, leading to a wide range of practical applications, ${ }^{2}$ and are being explored either as small molecules (as thin films formed by vacuum sublimation or solution processing) or inserted, as co-monomer units, in luminescent copolymers. ${ }^{3,4}$ To maximise light output, HTL materials should not absorb in the visible nor lead to significant light scattering (for which they must be

\footnotetext{
${ }^{a}$ INETI-DTIQ, Estrada do Paco do Lumiar, 22, Lisboa, 1649-038,

Portugal.E-mail: barbara.gigante@ineti.pt;

Fax: + 351 (0)217 168 100; Tel: + 351 (0)210924750

${ }^{b}$ Chemistry Group, School of Engineering, Swansea University,

Singleton Park, SA2 8PP Swansea, UK

${ }^{c}$ Departamento de Quimica, Universidade de Coimbra, Coimbra,

3004-535,Portugal.E-mail: burrows@ci.uc.pt;

Fax: + 351 (0)239 827703; Tel: + 351 (0) 239854482

${ }^{d}$ CEF, Faculdade de Farmácia, Universidade de Coimbra, Coimbra, 3000-295, Portugal

$\dagger$ Electronic supplementary information (ESI) available: Experimental data on hot stage microscopy (HSM) of compounds 3-9 and a thermogravimetric curve up to $650{ }^{\circ} \mathrm{C}$ for compound 7 are given in figures S1 and S2 of the ESI. See DOI: 10.1039/b815711a
}

amorphous). To avoid crystallisation, various derivatives (including polymers) with high glass transition temperatures $\left(T_{\mathrm{g}}\right)^{5-7}$ have been developed. One extensively used material for this purpose $^{5}$ is $N, N^{\prime}$-diphenyl- $N, N^{\prime}$-bis(3-methylphenyl)[1,1'-biphenyl]-4,4'-diamine (TPD), with a $T_{\mathrm{g}}$ of $60{ }^{\circ} \mathrm{C}{ }^{8}$ However, TPD films prepared by sublimation tend to crystallise over time, even at ambient temperature. To circumvent these problems, many efforts have been devoted to the synthesis of new HTL materials with better thermal and morphological stability, and there is strong interest in the development of amorphous molecular materials for these applications. ${ }^{1} \mathrm{We}$ have previously shown that triarylamines containing a bulky aryl-substituent (a dehydroabietic acid methyl ester moiety) 9,10 inhibit crystallisation and show good solubility characteristics. In addition, we have also indicated the potential of dehydroabietic acid based bipolar arylamine-quinoxalines for device applications. $^{11}$ Here, we take one step further and study the effect of stilbene substituents within a new series of compounds 3-8 (Fig. 1). The triarylamine 9, without the stilbene unit, was also studied for comparison with $\mathbf{8}$, in order to understand its emission behaviour.

In addition to their potential as HTL materials, ${ }^{12}$ the stilbene derivatives act as models for end-capped poly( $p$-phenylene vinylene)-based systems, which have been studied in more detail elsewhere. ${ }^{13}$ They may also possess interesting photonic properties, since arylamines with electron accepting nitro groups are amongst the most important organic systems in non-linear optics. ${ }^{14}$ Further, the enhanced solubility of these compounds suggests that they may be of interest as optical probes. Both the amorphous nature of these compounds and their good solubility characteristics favour many of these applications. We have therefore carried out a detailed study of the spectroscopic and electrochemical properties of these compounds, and have further characterised the photophysical behaviour both in solution and in rigid media. In addition, we have looked at the thermal properties using thermomicroscopy and thermogravimetry. 


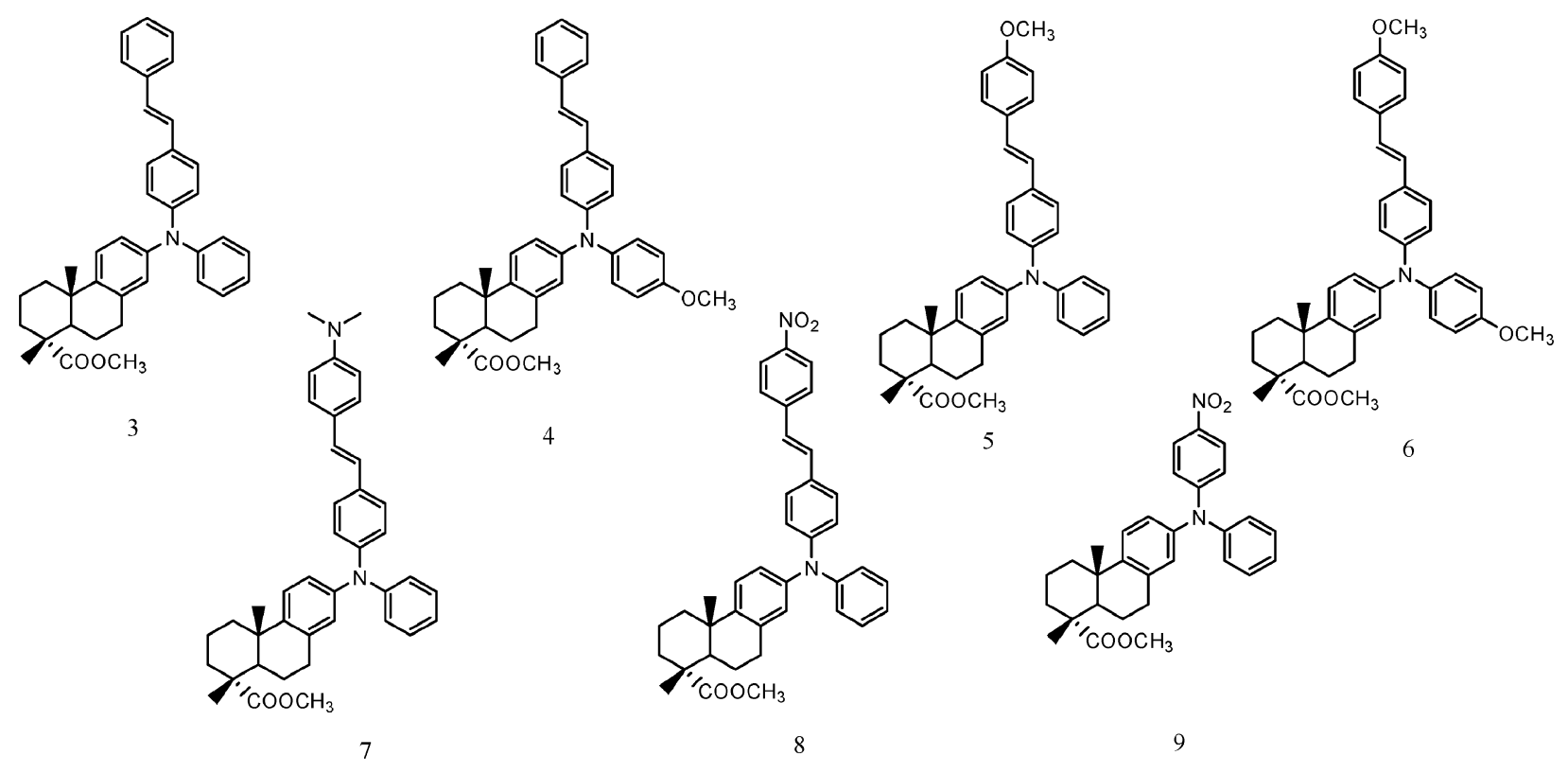

Fig. 1 Structures of new methyl dehydroabietic acid triarylamines 3-9.

The relevance of this to the film-forming properties of the compounds and their potential applications will be discussed.

\section{Results and discussion}

\section{Synthesis}

The synthetic pathway for the new stilbene-based triarylamines with dehydroabietic acid methyl ester moieties (3-8) is sketched out in Scheme 1. Different trans-4-bromostilbenes (1a-d), prepared by a Horner-Wadsworth-Emmons procedure, ${ }^{12}$ were coupled to the diarylamines $\mathbf{2 a}$ or $\mathbf{2 b}$ using a suitable palladium-catalysed route to aromatic carbon-nitrogen bond formation $\left(\mathrm{Pd}(\mathrm{OAc})_{2} / \mathrm{P}(t-\mathrm{Bu})_{3} / \mathrm{NaO} t-\mathrm{Bu}\right)^{15}$ to give the target compounds 3-8. The starting stilbenes 1a-d, the diarylamine intermediates $\mathbf{2 a}$ and $\mathbf{2 b}$ as well as the new stilbene-triarylamines 3-8 were purified by either repeated recrystallisation or by column chromatography. The triarylamine $\mathbf{9}$, without the stilbene moiety, was synthesised by reaction of $\mathbf{2 a}$ with 1-bromo-4-nitrobenzene using the same palladium-catalysed route. $^{15}$

The structures of the new compounds were confirmed by ${ }^{1} \mathrm{H}$ NMR spectroscopy, mass spectrometry and elemental analysis. All the triarylamines are soluble in commonly used organic solvents.

\section{Electrochemical, spectroscopic and photophysical studies}

To ensure that these new stilbene-based compounds (3-8) could be useful for fabrication of OLEDs, the electrochemical, spectroscopic and photophysical properties were studied in various solvents and under different conditions.

\section{Electrochemical properties}

The redox behaviour of the new compounds was studied by cyclic voltammetry in acetonitrile. All triarylamines show a

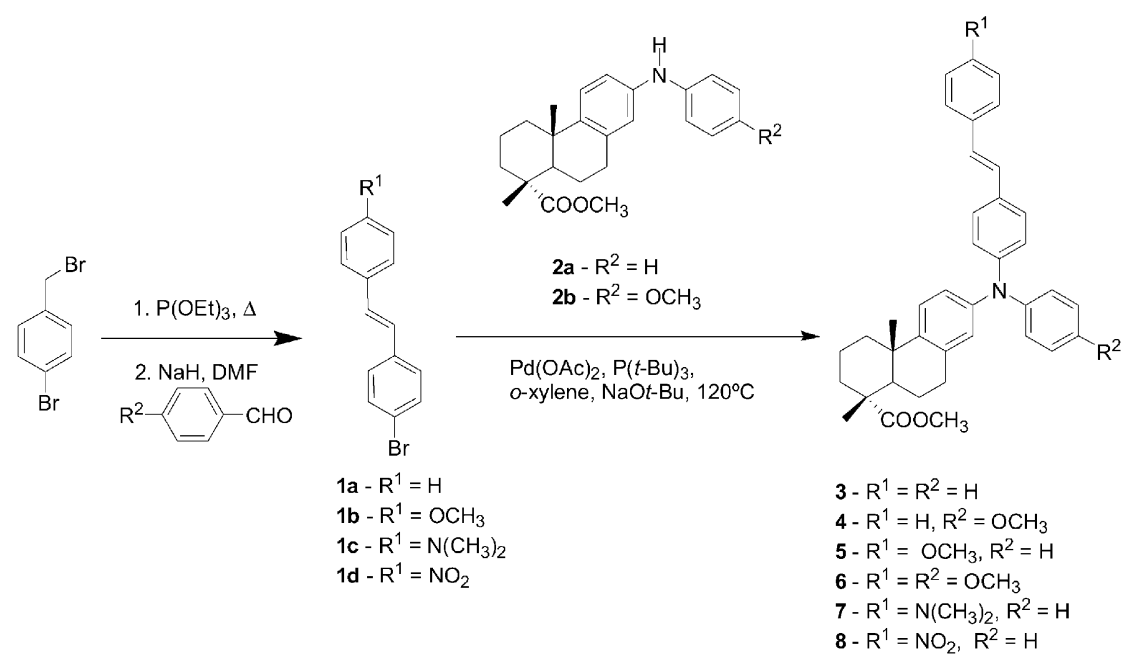

Scheme 1 
Table 1 Absorption and fluorescence data for triarylamines 3-9

\begin{tabular}{|c|c|c|c|c|c|c|c|}
\hline Cpd & Solvent & $E_{\mathrm{pa}} / \mathrm{V}^{a}$ & $\lambda_{\mathrm{abs} / \mathrm{nm}}$ & $\varepsilon_{\mathrm{abs}} \times 10^{4} / \mathrm{M}^{-1} \mathrm{~cm}^{-1 b}$ & $\lambda_{\mathrm{em}} / \mathrm{nm}$ & $\Phi_{\mathrm{f}}^{e}$ & $\tau_{\mathrm{f}}^{f} / \mathrm{ns}$ \\
\hline & Cyclohexane & & $371(269)$ & $3.64(2.26)$ & 404 & 0.34 & 1.60 \\
\hline \multirow[t]{3}{*}{3} & Acetonitrile & 0.77 & $367(293)$ & $2.81(2.81)$ & 479 & 0.68 & \\
\hline & Isopropanol & & $367(292)$ & $2.93(2.06)$ & 453 & 0.67 & \\
\hline & Cyclohexane & & $375(291)$ & $3.77(2.50)$ & 418 & 0.43 & 1.96 \\
\hline \multirow[t]{3}{*}{4} & Acetonitrile & 0.69 & 369 (289) & $3.70(2.50)$ & 517 & 0.27 & \\
\hline & Isopropanol & & $371(284)$ & $3.52(2.45)$ & 472 & 0.42 & \\
\hline & Cyclohexane & & 367 (298) & $3.90(2.90)$ & 400 & 0.39 & 1.29 \\
\hline \multirow[t]{3}{*}{5} & Acetonitrile & 0.74 & $365(294)$ & $4.05(2.96)$ & 473 & 0.56 & \\
\hline & Isopropanol & & $366(298)$ & $3.79(2.79)$ & 438 & 0.56 & \\
\hline & Cyclohexane & & $371(300)$ & $3.90(2.90)$ & 411 & 0.35 & 1.58 \\
\hline \multirow[t]{3}{*}{6} & Acetonitrile & c & $367(292)$ & $4.02(2.94)$ & 493 & 0.49 & \\
\hline & Isopropanol & & $370(296)$ & $3.56(2.71)$ & 471 & 0.54 & \\
\hline & Cyclohexane & & $379(300)$ & $4.82(2.64)$ & 410 & 0.50 & 1.26 \\
\hline \multirow[t]{3}{*}{7} & Acetonitrile & 0.52 & $373(302)$ & $4.15(3.31)$ & 445 & 0.24 & \\
\hline & Isopropanol & & $377(290)$ & $4.24(2.65)$ & 436 & 0.29 & \\
\hline & Cyclohexane & & $432(301)$ & $3.29(3.17)$ & 483 & 0.57 & 2.38 \\
\hline \multirow[t]{3}{*}{8} & Acetonitrile & 0.84 & $428(301)$ & $2.96(3.31)$ & $\mathrm{N} / \mathrm{E}^{d}$ & $\mathrm{~N} / \mathrm{A}$ & \\
\hline & Isopropanol & & $430(289)$ & $2.83(2.84)$ & $\mathrm{N} / \mathrm{E}^{d}$ & $\mathrm{~N} / \mathrm{A}$ & \\
\hline & Cyclohexane & & $388(287)$ & $1.90(1.35)$ & 495 & 0.50 & 1.05 \\
\hline \multirow[t]{2}{*}{9} & Acetonitrile & $c$ & $398(264)$ & $2.14(1.60)$ & $\mathrm{N} / \mathrm{E}^{d}$ & $\mathrm{~N} / \mathrm{A}$ & \\
\hline & Isopropanol & & $397(283)$ & $1.43(1.04)$ & $\mathrm{N} / \mathrm{E}^{d}$ & $\mathrm{~N} / \mathrm{A}$ & \\
\hline
\end{tabular}

reversible first step upon oxidation. For triarylamines $\mathbf{3}, \mathbf{4}$ and 5 a second oxidation peak at more positive potential with no cathodic counterpart in the reverse scan is observed indicating that the oxidative process is associated with consecutive chemical reactions of the initially formed radical cation. In the case of $\mathbf{8}$ a cathodic redox process attributed to reaction of the nitro substituent was noticed. In 7 a second quasireversible oxidation process closely overlapped with the first one, and can be attributed to the oxidation of the dimethylamino group. The first oxidation potentials are presented in Table 1. From the data, it can be seen that the increase of the electron-releasing character of the substituent in the aryl moiety shifts the first oxidation potential cathodically. This effect, which has also been observed in diarylamines derived from the dehydroabietic acid, ${ }^{16}$ is explained by the ability of these substituents to inductively delocalise the charge in the radical cation, thus improving its stability.

\section{Spectroscopic and photophysical studies}

Absorption spectra of the seven triarylamines were recorded in cyclohexane, acetonitrile and isopropanol, and showed a lowest energy absorption band around $370 \pm 10 \mathrm{~nm}$, which was only slightly dependent on substituents and solvent. In contrast, a strong solvent dependence was seen in the fluorescence spectra, with the most marked Stokes shifts occurring in acetonitrile. In addition, significant substituent effects were observed in both emission maxima and quantum yields, and in the case of compound $\mathbf{8}$ and the derivative $\mathbf{9}$ without the stilbene unit, no emission was observed in the polar solvents acetonitrile and isopropanol. In the case of compounds 8 and 9, the absence of emission and the presence of the electron-withdrawing $\mathrm{NO}_{2}$ group suggest that the lowest lying singlet excited state is forbidden and $n, \pi^{*}$, based, while both the solvent and substituent effects suggest considerable charge transfer character in the emitting level. ${ }^{12,17}$ Spectral data for these compounds are summarised in Table 1. Typical absorption and emission spectra are shown in Fig. 2.

A more detailed study of the photophysical properties was made in cyclohexane solution. The fluorescence quantum yields were markedly higher than those of related dehydroabietic
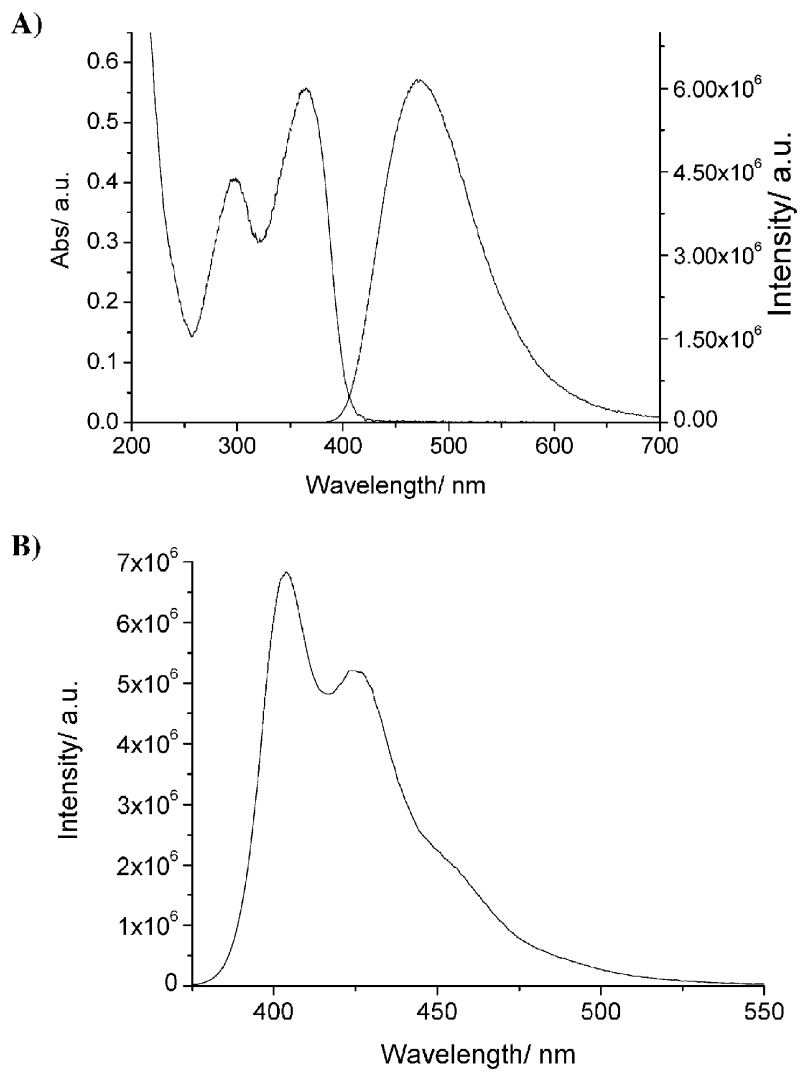

Fig. 2 Typical spectra: (A) absorption (left) and emission (right) of 5 in acetonitrile; (B) fluorescence spectrum of $\mathbf{3}$ in cyclohexane. 
acid based diarylamines in the same solvent. ${ }^{18}$ Although in part this may be due to the presence of the strongly fluorescent $N$-phenylaminostilbene group, ${ }^{12}$ the fact that compound $\mathbf{9}$, lacking this moiety, also has a relatively high fluorescence yield shows that this is not the only factor. The observation of high luminescent yields is relevant to the potential of these compounds either as probes or in light-emitting devices. Fluorescence lifetimes were measured in this solvent, and radiative lifetimes calculated using these and quantum yields. They were also determined from the integral absorption and emission band using the Strickler-Berg (SB) relationship (eqn (1)): ${ }^{19,20}$

$$
(\tau)^{-1}=2.88 \times 10^{-9} n^{2}\left[\left\langle\nu_{\mathrm{f}}^{-3}\right\rangle\right]^{-1}\left[\int\left(\frac{\varepsilon\left(\nu_{\mathrm{a}}\right)}{\nu_{\mathrm{a}}}\right) \mathrm{d} \nu\right]
$$

where $n$ is the solvent refractive index; $\varepsilon$ is the molar absorption coefficient and the integration of this term is only over the lowest energy absorption band; $\nu$ is the frequency of the transition in $\mathrm{cm}^{-1}$. The term $\nu_{\mathrm{f}}^{-3}$ was determined from the integral of the emission spectrum, in terms of corrected intensities in units of relative numbers of quanta at each frequency, divided by the integral of the emission spectrum at $\nu^{-3}$ times this value. All data are summarised in Table 2. The radiative lifetimes calculated from the Strickler-Berg relationship are, in all cases, slightly lower than those obtained from fluorescence quantum yields and lifetimes. The long wavelength absorption band corresponds to various overlapping electronic transitions, both from different conformation and excited states, and a likely explanation for the differences in experimental and calculated radiative lifetimes is that the lowest energy $\left(\mathrm{S}_{0} \rightarrow \mathrm{S}_{1}\right)$ transition is a weak band buried in the more intense absorption around $370 \mathrm{~nm}$, such that the molar absorption coefficients used in the Strickler-Berg calculation are too high and thus give an underestimation of the radiative lifetime. This again suggests the presence of a forbidden transition (likely to be of $n, \pi^{*}$ origin) as the lowest lying transition in the case of compound 9, whereas with the other compounds a less intense, but still allowed, transition (of $\pi, \pi^{*}$ origin in view of the $\tau_{\text {radiative }}(\mathrm{SB})$ values in Table 2) is responsible for the $S_{0} \rightarrow S_{1}$ transition. As we will see later, further clarification on the origin of the nature of this lowest lying excited state can be drawn from fluorescence anisotropy studies of the excitation spectra of these compounds in a rigid medium.

Fluorescence spectra were also measured in a methylcyclohexane glass at liquid nitrogen temperature, and are compared
Table 3 Comparison of the low temperature fluorescence results in methylcyclohexane glass with those in cyclohexane solution at room temperature

\begin{tabular}{llllll}
\hline & \multicolumn{2}{l}{ Room temperature } & & \multicolumn{2}{c}{ Low temperature } \\
\cline { 2 - 3 } Compound & $\lambda_{\text {max }} / \mathrm{nm}$ & $\Phi_{\mathrm{f}}$ & & $\lambda_{\text {max }} / \mathrm{nm}$ & $\Phi_{\mathrm{f}}$ \\
\hline $\mathbf{3}$ & 404 & 0.34 & & 408 & 0.67 \\
$\mathbf{4}$ & 418 & 0.43 & & 418 & 0.75 \\
$\mathbf{5}$ & 400 & 0.39 & 403 & 0.72 \\
$\mathbf{6}$ & 411 & 0.35 & 413 & 0.95 \\
$\mathbf{7}$ & 410 & 0.50 & & 416 & 0.80 \\
$\mathbf{8}$ & 483 & 0.57 & 484 & 0.68 \\
$\mathbf{9}$ & 495 & 0.50 & 510 & 0.93 \\
\hline
\end{tabular}

with room temperature measurements in Table 3. Slight red shifts in emission maxima were observed, and were accompanied by dramatic increases in fluorescence quantum yields, which in some cases approached unity. We believe that this is due to the increased rigidity in the glasses, which makes non-radiative decay of the lowest stilbene-triarylamine excited states more difficult. It is likely that the freedom of rotation around the $\mathrm{N}$-aromatic bonds is responsible for the importance of the radiationless channel at $293 \mathrm{~K}$ (which has been termed the loose bolt effect ${ }^{21}$ ), whereas at $77 \mathrm{~K}$ this deactivation channel vanishes due to the rigidity imposed to the system. Such effects of increased rigidity will also be present in thin films used in electro-optic devices and are likely to favour application of these materials in OLEDs.

\section{Fluorescence anisotropy study}

The anisotropy of the nitro-substituted triarylamine 9 was studied in polar solvents of varying viscosity; it has already been shown that its emission is quenched by polar solvents at room temperature. The spectra of 9 were recorded at $77 \mathrm{~K}$ in a mixture of methanol and ethanol (4:1 ratio) in order to determine if the fluorescence is quenched at low temperature in polar conditions. At $77 \mathrm{~K}$ quenching is not observed, and in both cases the fluorescence quantum yield is high, with values of 0.83 and 0.85 obtained for $\mathbf{9}$ and $\mathbf{8}$, respectively. This is most likely to be due to the fact that at $77 \mathrm{~K}$ the compounds cannot undergo molecular torsion, i.e. at $77 \mathrm{~K}$ emission is from a Franck-Condon excited state to a planar ground state whereas at room temperature deactivation is predominantly nonradiative via a twisted excited state. A similar pattern has been described for oligo and polythiophene derivatives. ${ }^{22,23}$

Compound 9 was dissolved in diisodecyl phthalate (DIDP), which is a very viscous solvent. ${ }^{24}$ The anisotropy of 9 was

Table 2 Fluorescence quantum yields, lifetimes and radiative lifetimes in cyclohexane

\begin{tabular}{lllll}
\hline Compound & $\Phi_{\mathrm{f}}{ }^{a}$ & $\tau_{\mathrm{f}}( \pm 0.05) / \mathrm{ns}$ & Radiative lifetime $^{b}( \pm 0.10) / \mathrm{ns}$ & Calculated radiative lifetime $^{c} / \mathrm{ns}$ \\
\hline $\mathbf{3}$ & 0.34 & 1.60 & 4.71 & 1.74 \\
$\mathbf{4}$ & 0.43 & 1.96 & 4.56 & 2.21 \\
$\mathbf{5}$ & 0.39 & 1.29 & 3.31 & 1.08 \\
$\mathbf{6}$ & 0.35 & 1.58 & 4.51 & 1.83 \\
$\mathbf{7}$ & 0.50 & 1.26 & 2.52 & 1.59 \\
$\mathbf{8}$ & 0.57 & 2.38 & 2.18 & 8.19 \\
$\mathbf{9}$ & 0.50 & 1.05 & & \\
${ }^{a}$ In cyclohexane solution with $\alpha-4$-oligothiophene as reference. ${ }^{b}$ Calculated from quantum yield $\left(\Phi_{\mathrm{f}}\right)$ and lifetime $\left(\tau_{\exp }\right)$ using $\tau_{\text {rad }}=\tau_{\text {exp }} / \Phi_{\mathrm{f}}$. \\
${ }^{c}$ Calculated from the Strickler-Berg relationship. \\
\hline
\end{tabular}


Table 4 Fluorescence anisotropy results for compound 9

\begin{tabular}{lll}
\hline Sample & Solvent & Anisotropy value \\
\hline $\mathbf{9}^{a}$ & Methylcyclohexane & 0.56 \\
$\mathbf{9}$ & DIDP & 0.23 \\
$\mathbf{9}$ & DIDP $+5 \mu \mathrm{lEG}$ & 0.19 \\
$\mathbf{9}$ & DIDP $+15 \mu \mathrm{l}$ PEG & 0.18 \\
$\mathbf{9}$ & DIDP $+30 \mu \mathrm{PEG}$ & 0.15 \\
$\mathbf{9}$ & DIDP $+100 \mu \mathrm{l} \mathrm{PEG}$ & 0.07 \\
${ }^{a}$ Carried out at & $77 \mathrm{~K}$, all other samples were at room temperature. \\
\hline
\end{tabular}

then monitored upon the addition of the polar and relatively non-viscous polyethylene glycol 2000 (PEG).

The observed value for methylcyclohexane is above the theoretical maximum anisotropy (0.4), probably due to problems with light scattering, and should be taken as showing that there is no depolarisation during the fluorescence lifetime of 9. The other results show, as expected, that frozen in a 'glass' or in a highly viscous solution $\mathbf{9}$ has a relatively high anisotropy value. The anisotropy value then decreases with a decrease in viscosity (Table 4). This is due to the fact that as the viscosity decreases it becomes easier for it to undergo molecular torsion (i.e. emission is from a twisted excited state to a twisted ground state).

In summary both $\mathbf{9}$ and $\mathbf{8}$, which contain the strongly electron-withdrawing $-\mathrm{NO}_{2}$ group, show unusual behaviour. Emission changes significantly with solvent polarity; there is a red shift with complete loss of structure of the emission band, and a marked reduction in emission intensity as solvent polarity is increased. This may be understood in terms of a close lying twisted charge transfer state, the position of which is solvent dependent. This is supported by the data from the low temperature emission spectra as quenching does not occur in a rigid glass at low temperatures due to the fact that the compounds cannot undergo molecular torsion. This suggests that room temperature deactivation in fluid solution is predominantly non-radiative via a twisted CT excited state to a twisted ground state, whereas emission in a rigid glass at low temperatures or in a highly viscous environment is from a planar excited state to a planar ground state.

\section{Hot stage microscopy studies and thermogravimetric analysis}

Hot stage microscopy (HSM) was carried out on all seven samples as previously described. ${ }^{9}$ Table 5 shows the onset of melting temperature and the melting point range of all the compounds; this is also shown as ESI $\dagger$ (Fig. SI 1, which is the graphical representation of these results). The differences between the onset of melting temperature and the melting

Table 5 HSM results summary showing the onset temperature along with the melting point range of all the compounds

\begin{tabular}{lcc}
\hline Compound & Onset temperature $/{ }^{\circ} \mathrm{C}$ & Melting point range $/{ }^{\circ} \mathrm{C}$ \\
\hline $\mathbf{3}$ & 176.0 & $176-178$ \\
$\mathbf{4}$ & 92.6 & $98-102$ \\
$\mathbf{5}$ & 106.8 & $113-117$ \\
$\mathbf{6}$ & 86.1 & $100-108$ \\
$\mathbf{7}$ & 175.7 & $177-180$ \\
$\mathbf{8}$ & 182.5 & $182-185$ \\
$\mathbf{9}$ & 80.0 & $85-93$ \\
\hline
\end{tabular}

Table 6 TGA results; thermal decomposition temperatures for all the compounds

\begin{tabular}{ll}
\hline Compound & $\begin{array}{l}\text { Thermal decomposition } \\
\text { temperature }\left(T_{\mathrm{d}}\right) /{ }^{\circ} \mathrm{C}\left( \pm 5{ }^{\circ} \mathrm{C}\right)\end{array}$ \\
\hline $\mathbf{3}$ & 357 \\
$\mathbf{4}$ & 361 \\
$\mathbf{5}$ & 302 \\
$\mathbf{6}$ & 323 \\
$\mathbf{7}$ & 367 \\
$\mathbf{8}$ & 313 \\
$\mathbf{9}$ & 300 \\
\hline
\end{tabular}

point range arise due to the fact that the onset of melting temperature is the value calculated from the extrapolation of the intensity curves whereas the melting point range is the observed value. The HSM shows that these compounds do not crystallise readily; the compounds have also been kept in a small sample for a time period greater than a year with no crystallisation.

Thermogravimetric analysis (TGA) was also carried out on all seven samples in order to determine the thermal properties and in particular the degradation temperatures of the compounds. A typical thermogram, for compound 7, is shown as $\mathrm{ESI} \dagger$ (Fig. SI 2). TGA showed that all compounds were stable in nitrogen, with thermal degradation temperatures $\left(T_{\mathrm{d}}\right)$ equal to or greater than $300{ }^{\circ} \mathrm{C}$ (Table 6). It is important that the thermal degradation temperatures are above $300{ }^{\circ} \mathrm{C}$ in order to be well above operating temperatures of relevant devices and also so that the compounds can be applied using vacuum deposition techniques. Also a high thermal degradation temperature means a wider temperature range in which the compounds could be used, possibly leading to a wider range of applications.

During thermogravimetric analysis it was also found that some of the compounds sublime. This was confirmed by recording a UV/VIS spectrum of the sublimate and comparing it to the known spectrum of that compound. Only two compounds out of the seven (compounds $\mathbf{8}$ and 9 ) did not sublime.

\section{Conclusions}

The presence of a bulky dehydroabietic acid moiety in a series of stilbene-based triarylamines has been shown to produce thermally stable, soluble and vacuum sublimable materials without adversely affecting their electrochemical, optical or photophysical properties. These compounds can be used for preparation of thin films which do not crystallise readily. In addition, in some cases the presence of the bulky groups seems to enhance their fluorescence emission properties. These properties make the compounds attractive materials for a variety of applications in molecular electronics. Their potential applications as hole transport layers in LEDs are being studied in detail and will be reported elsewhere.

\section{Experimental}

\section{Materials}

Reagents were of the purest grade available, and generally were used without further treatment. The stilbenes $\mathbf{1 a - d}$, as 
well as the diarylamines $\mathbf{2} \mathbf{a}$ and $\mathbf{2 b}$, were prepared as described below. Tetrabutylammonium hexafluorophosphate (98\%) used for cyclic voltammetry (CV) was purified by recrystallisation from ethanol and dried under vacuum prior to use. Acetonitrile P.A. grade was distilled twice, first over $\mathrm{CaH}_{2}$ and then over $\mathrm{P}_{2} \mathrm{O}_{5}$, under nitrogen. Other solvents were dried according to standard methods. ${ }^{25}$

\section{Equipment and methods}

FTIR spectra were recorded on a Perkin-Elmer 1725 spectrometer. Fourier transform (FT) NMR spectra were run on a General Electric QE-300 spectrometer with resonance frequency of $300.65 \mathrm{MHz}$ for ${ }^{1} \mathrm{H}$ and $75.6 \mathrm{MHz}$ for ${ }^{13} \mathrm{C}$, using an appropriate solvent. The chemical shifts are reported in $\delta$ (ppm, TMS) and coupling constants in Hz. EI mass spectra were determined on a Kratos MS 25RF instrument at $70 \mathrm{eV}$. Microanalyses were performed on a Carlo Erba 1106R microanalyser. The electrochemical instrumentation for cyclic voltammetry (CV) consisted of an EG\&G Princeton Applied Research Potentiostat Model 273A, connected to the data acquisition software (EG\&G PAR Electrochemical Analysis Model 273 version 3.0). A three-electrode system was used, with a platinum counter electrode, a platinum working electrode and a potassium chloride saturated calomel reference electrode (SCE). A $10^{-1} \mathrm{M}$ solution of tetrabutylammonium hexafluorophosphate in acetonitrile was used as the supporting electrolyte. The solutions used in the cyclic voltammetry studies contained $5 \mathrm{mM}$ triarylamine in $0.1 \mathrm{M}$ of supporting electrolyte. Solutions were degassed and kept under nitrogen throughout each experiment. Measurements were conducted at $25 \pm 0.1{ }^{\circ} \mathrm{C}$ using a sweep rate of $50 \mathrm{mV} \mathrm{s}^{-1}$. We used ferrocene/ferrocinium $\left(\mathrm{Fc} / \mathrm{Fc}^{+}=+0.41 \mathrm{~V}\right)$ to calibrate the SCE. Thin layer chromatography (TLC) was performed on silica gel $60 \mathrm{~F} 254$ plates with $0.2 \mathrm{~mm}$ layer thickness from Macherey-Naguel, and the compounds visualised by illumination under UV light at $254 \mathrm{~nm}$. Column chromatography was carried out with Macherey-Naguel Si gel 60 (230-400 mesh).

Absorption spectral measurements were made on solutions in $1 \mathrm{~cm}$ quartz cuvettes on a Shimadzu UV-2100 spectrophotometer. Molar absorption coefficients were determined from slopes of absorbance as a function of concentration for a series of solutions for each compound at various concentrations. Fluorescence spectra and quantum yields were measured in $1 \mathrm{~cm}$ quartz cuvettes using 90 degree geometry on a Jobin Yvon-Spex Fluorolog 3-22 instrument. Emission and excitation spectra were corrected for variation in spectral response of the light source (a $450 \mathrm{~W}$ xenon lamp), monochromator and detector. Quantum yields were determined for optically matched solutions from the ratio of integrated corrected emission spectra. ${ }^{26}$ Tetrathiophene was used as reference. ${ }^{22}$ Absorption and fluorescence spectra at $77 \mathrm{~K}$ were run with a Perkin-Elmer Lambda 5 UV/VIS spectrophotometer and a Jobin Yvon JY3D spectrofluorimeter, respectively.

Fluorescence decays were measured using a home-built time-correlated single photon counting apparatus with an $\mathrm{N}_{2}$ filled IBH 5000 coaxial flashlamp as excitation source, Jobin-Ivon monochromator, Philips XP2020Q photomultiplier and Canberra instruments time-to-amplitude converter and multichannel analyser. Alternate measurements (1000 counts per cycle), controlled by Decay ${ }^{\circledR}$ software (Biodinâmica-Portugal), of the pulse profile at 337 or $356 \mathrm{~nm}$ and the sample emission were performed until 1-2 $\times 10^{4}$ counts at the maximum were reached. ${ }^{27}$ The fluorescence decays were analysed using the modulating functions method of Striker with automatic correction for the photomultiplier "wavelength shift." 28 Thermogravimetric analysis was carried out with a Rheometric Scientific Simultaneous Thermal Analyser (STA). All samples were run in a nitrogen atmosphere and were heated from $30-625{ }^{\circ} \mathrm{C}$ at a rate of $10{ }^{\circ} \mathrm{C} \mathrm{min}{ }^{-1}$. Sample masses that were used were in the range of $0.5-1 \mathrm{mg}$; all samples were run under identical conditions.

\section{Synthesis}

\section{General procedure for the trans-4-bromostilbenes (1a-d)}

trans-4-Bromostilbenes 1a-d used in this work were prepared (Scheme 1) by a reaction previously described. ${ }^{12}$ A mixture of bromobenzylbromide $(4.00 \mathrm{mmol})$ and triethylphosphite $\mathrm{P}(\mathrm{OEt})_{3}(4.80 \mathrm{mmol})$ was heated at $150{ }^{\circ} \mathrm{C}$ for $3 \mathrm{~h}$ under argon. The solution was cooled and then $10 \mathrm{~mL}$ of anhydrous DMF were added. The solution was placed in an ice bath for $15 \mathrm{~min}$ and then $\mathrm{NaH}(60 \%$ in mineral oil) $(6 \mathrm{mmol})$ was added. The mixture was stirred for $20 \mathrm{~min}$ and then the appropriate benzaldehyde $(4.00 \mathrm{mmol})$ was slowly added. The mixture was stirred for $12 \mathrm{~h}$ before it was decanted into ice water. Further purification was performed by recrystallisation.

With benzaldehyde $(0.41 \mathrm{~mL})$, trans-(4-bromostyryl)benzene 1a was afforded $(0.88 \mathrm{~g}, 85 \%)$ as white crystals $\mathrm{mp}$ 132-135 ${ }^{\circ} \mathrm{C}$ (from $\mathrm{CH}_{2} \mathrm{Cl}_{2}-\mathrm{MeOH}$ ) (lit. ${ }^{12} 132-133{ }^{\circ} \mathrm{C}$ ); $\delta_{\mathrm{H}}$ (300 MHz, $\left.\mathrm{CDCl}_{3}, \mathrm{Me}_{4} \mathrm{Si}\right) 7.03(1 \mathrm{H}, \mathrm{d}, J 16.2), 7.11(1 \mathrm{H}, \mathrm{d}$, $J$ 16.2), 7.27 (1H, t, $J$ 6.0), 7.34-7.40 (4H, m), 7.47-7.53 $(4 \mathrm{H}, \mathrm{m}) ; \delta_{\mathrm{C}}\left(75 \mathrm{MHz}, \mathrm{CDCl}_{3}, \mathrm{Me}_{4} \mathrm{Si}\right) 121.3(C-\mathrm{Br}), 126.5$ (2C); 127.4 (C-Olef), 127.9 (C), 127.9 (2C), 128.7 (2C), 129.4 (C-Olef), 131.7 (2C), 136.2 (C), 136.9 (C).

With 4-methoxybenzaldehyde (0.54 g), trans-4-(4-bromostyryl)methoxybenzene (1b) was afforded $(0.92 \mathrm{~g}, 80 \%)$ as a white solid mp 202-204 ${ }^{\circ} \mathrm{C}$ (from $\mathrm{CH}_{2} \mathrm{Cl}_{2}-\mathrm{MeOH}$ ); $\left(\mathrm{BrC}_{15} \mathrm{H}_{13} \mathrm{O}\right.$ requires $\mathrm{C} 62.30, \mathrm{H}$ 4.53; found $\mathrm{C}$ 62.29, $\mathrm{H}$ 4.31); $\nu_{\max }(\mathrm{KBr}) / \mathrm{cm}^{-1} 1604,1513,1254,969 ; \delta_{\mathrm{H}}(300 \mathrm{MHz}$, $\left.\mathrm{CDCl}_{3}, \mathrm{Me}_{4} \mathrm{Si}\right) 3.83,(3 \mathrm{H}, \mathrm{s}), 6.89(1 \mathrm{H}, \mathrm{d}, J 16.2), 6.90(2 \mathrm{H}, \mathrm{d}$, $J$ 8.5), 7.04 (1H, d, $J$ 16.2), $7.34(2 \mathrm{H}, \mathrm{d}, J$ 8.5), 7.42-7.47 $(4 \mathrm{H}, \mathrm{m}) ; \delta_{\mathrm{C}}\left(75 \mathrm{MHz}, \mathrm{CDCl}_{3}, \mathrm{Me}_{4} \mathrm{Si}\right) 55.3\left(\mathrm{O}-\mathrm{CH}_{3}\right) 114.1$ (2C), 120.7 (C-Br), 125.2 (C-Olef), 127.7 (2C); 127.8 (2C), 128.9 (C-Olef), 129.7 (C9), 131.7 (2C), 136.6 (C), 159.5 (C); $m / z$ (EI) $290\left(\mathrm{M}^{+}{ }^{81} \mathrm{Br}, 97 \%\right), 289.0\left(\mathrm{M}^{+}{ }^{79} \mathrm{Br}, 100\right)$.

With 4-nitrobenzaldehyde (0.60 g), trans-4-(4-bromostyryl)nitrobenzene (1c) was obtained $(0.96 \mathrm{~g}, 79 \%)$ as a white solid mp 215-217 ${ }^{\circ} \mathrm{C}$ (from $\mathrm{CH}_{2} \mathrm{Cl}_{2}-\mathrm{MeOH}$ ); $\left(\mathrm{BrC}_{14} \mathrm{H}_{10} \quad \mathrm{NO}_{2}\right.$ requires $\mathrm{C} 55.29, \mathrm{H} 3.31, \mathrm{~N} 4.61$; found $\mathrm{C} 55.13, \mathrm{H} 3.05$, $\mathrm{N} 4.86) ; \nu_{\max }(\mathrm{KBr}) / \mathrm{cm}^{-1} 1592,1506,1340,945 ; \delta_{\mathrm{H}}(300 \mathrm{MHz}$, $\left.\mathrm{CDCl}_{3}, \mathrm{Me}_{4} \mathrm{Si}\right) 7.12(1 \mathrm{H}, \mathrm{d}, J 16.2), 7.20(1 \mathrm{H}, \mathrm{d}, J 16.2), 7.41$ (2H, d, $J$ 9.0), $7.53(2 \mathrm{H}, \mathrm{d}, J 9.0), 7.63(2 \mathrm{H}, \mathrm{d}, J 9.0), 8.22$ $(2 \mathrm{H}, \mathrm{d}, J 9.0) ; \delta_{\mathrm{C}}\left(75 \mathrm{MHz}, \mathrm{CDCl}_{3}, \mathrm{Me}_{4} \mathrm{Si}\right) 122.2$ (C-Br), 124.2 (2C), 126.9 (C-Olef and 3C); 128.4 (2C), 131.9 (C-Olef), 132.0 (2C), 135.1 (C), 143.7 (C), 146.9 (C); $m / z$ (EI) $305\left(\mathrm{M}^{+}{ }^{81} \mathrm{Br}\right.$, 41\%), $303\left(\mathrm{M}^{+}{ }^{79} \mathrm{Br}, 42\right), 178$ (100). 
With 4-dimethylaminobenzaldehyde $(0.60 \mathrm{~g})$, trans-4(4-bromostyryl)dimethylaniline (1d) was afforded (0.80 g, 66\%) as a pale yellow solid mp $205-207{ }^{\circ} \mathrm{C}$ (from $\mathrm{CH}_{2} \mathrm{Cl}_{2}-n$-hexane), $\left(\mathrm{BrC}_{16} \mathrm{H}_{16} \mathrm{~N}\right.$ requires $\mathrm{C}$ 63.56, $\mathrm{H}$ 5.34, N 4.63; found $\mathrm{C} 63.88$, $\mathrm{H} 5.08, \mathrm{~N} 4.54) ; \nu_{\max }(\mathrm{KBr}) / \mathrm{cm}^{-1} 3448,1605,1351,966 ; \delta_{\mathrm{H}}$ (300 $\left.\mathrm{MHz} \mathrm{CDCl}_{3}, \mathrm{Me}_{4} \mathrm{Si}\right) 2.99(6 \mathrm{H}, \mathrm{s}), 6.71(2 \mathrm{H}, \mathrm{d}, J$ 8.7), $6.83(1 \mathrm{H}, \mathrm{d}, J 16,2), 7.03(1 \mathrm{H}, \mathrm{d}, J 16,2), 7.26-7.45(6 \mathrm{H}, \mathrm{m})$; $\delta_{\mathrm{C}}\left(75 \mathrm{MHz}, \mathrm{CDCl}_{3}, \mathrm{Me}_{4} \mathrm{Si}\right) 40.4\left(\mathrm{~N}-\left(\mathrm{CH}_{3}\right)_{2}\right), 112.4(2 \times$ $C$-Ar), 120.1 (C-Br), 123.0 (C-Olef), $125.3(\mathrm{C}), 127.5(2 \mathrm{C})$; 127.7 (2C), 129.6 (C-Olef), 131.7 (2C), 137.2 (C), 150.3 (C); $m / z$ (EI) $303\left(\mathrm{M}^{+}{ }^{79} \mathrm{Br}, 96 \%\right), 301\left(\mathrm{M}^{+}{ }^{79} \mathrm{Br}, 100\right), 183$ (44).

\section{Diarylamine synthesis}

Methyl 13-(phenyl)aminodeisopropyldehydroabietate (2a). Triphenylbismuth diacetate ${ }^{16}(0.85 \mathrm{~g}, 1.52 \mathrm{mmol})$ was added in small portions with stirring to a mixture of methyl 13-aminodesisopropyldehydroabietate ${ }^{29}(0.40 \mathrm{~g}, 1.38 \mathrm{mmol})$ and copper acetate $(0.025 \mathrm{~g}, 0.138 \mathrm{mmol})$ in dry dichloromethane $(15 \mathrm{~mL})$. After $5 \mathrm{~min}$ the reaction mixture was poured into a solution of $3 \mathrm{M}$ hydrochloric acid, the organic phase separated, washed with a $10 \%$ sodium bicarbonate solution and brine and dried over anhydrous sodium sulfate. The residue obtained after filtration and evaporation of the solvent was purified by silica column chromatography using a mixture of diethyl ether-petroleum ether $(3.5: 6.5)$ as eluent. The product was isolated as a white foam $(0.42 \mathrm{~g}, \eta=83 \%)$, $\left(\mathrm{C}_{24} \mathrm{H}_{29} \mathrm{NO}_{2}\right.$ requires $\mathrm{C} 79.30, \mathrm{H} 8.04, \mathrm{~N} 3.85$; found $\mathrm{C} 78.98$, $\mathrm{H} 8.24, \mathrm{~N} 3.72) ; \nu_{\max }(\mathrm{KBr}) / \mathrm{cm}^{-1} 3382,2928,1723,1598$, 1498, 1248, 694; $\delta_{\mathrm{H}}\left(300 \mathrm{MHz}, \mathrm{CDCl}_{3}, \mathrm{Me}_{4} \mathrm{Si}\right) 1.18$ $\left(3 \mathrm{H}, \mathrm{s}, \mathrm{CH}_{3}\right), 1.27\left(3 \mathrm{H}, \mathrm{s}, \mathrm{CH}_{3}\right), 1.36-1.53(2 \mathrm{H}, \mathrm{m}, 2 \mathrm{H}$, $2 \times \mathrm{CH}) 1.63-1.89\left(5 \mathrm{H}, \mathrm{m}, 2 \times \mathrm{CH}_{2}\right.$ and $\left.\mathrm{CH}\right), 2.23(1 \mathrm{H}, \mathrm{dd}$, $J 12$ and $2.1 \mathrm{~Hz}, \mathrm{CH}), 2.27$ (1H, brd, $J$ 13, CH), 2.81-2.84 $\left(2 \mathrm{H}, \mathrm{m}, \mathrm{CH}_{2}\right), 3.66\left(3 \mathrm{H}, \mathrm{s}, \mathrm{CH}_{3}\right), 5.60(1 \mathrm{H}$, brs, $\mathrm{NH}), 6.75(1 \mathrm{H}$, $\mathrm{d}, J 2.1, \mathrm{CH}), 6.85-6.89(2 \mathrm{H}, \mathrm{m}, 2 \times \mathrm{CH}), 6.99-7.02(2 \mathrm{H}, \mathrm{m}$, $2 \times \mathrm{CH}), 7.13(1 \mathrm{H}, \mathrm{d}, J$ 8.7, CH), 7.20-7.25 (2H, m, $2 \times \mathrm{CH})$. $\delta_{\mathrm{C}}\left(75 \mathrm{MHz}, \mathrm{CDCl}_{3}, \mathrm{Me}_{4} \mathrm{Si}\right) 16.5,18.6,21.7,25.2,30.1,36.7$, $36.8,38.1,45.1,47.7,52.0,116.3,117.3,118.2,120.4,125.2$, 129.3, 136.1, 140.3, 142.9, 143.7, 179.2. MS (EI): $m / z(\%) 363$ $\left(\mathrm{M}^{+}, 39\right), 348$ (33), 288 (55), 59 (100).

Methyl 13-(4-methoxyphenyl)aminodeisopropyldehydroabietate (2b). To a solution of methyl 13-aminodesisopropyldehydroabietate $^{29}$ (1 mmol, $\left.0.29 \mathrm{~g}\right)$ and copper diacetate $(0.1 \mathrm{mmol}, 18 \mathrm{mg})$ in dry dichloromethane $(10 \mathrm{~mL})$ was added, in small portions, 4-methoxyphenyllead triacetate $^{30}$ ( $1.1 \mathrm{mmol}, 0.54 \mathrm{~g})$. The mixture was stirred at room temperature, under $\mathrm{N}_{2}$, until the complete consumption of the amine (TLC, $1 \mathrm{~h}$ ). The reaction mixture was filtered through celite, concentrated under reduced pressure and purified by silica column chromatography $\left(\mathrm{Et}_{2} \mathrm{O}\right.$-petroleum ether, $\left.1: 1\right)$. The product $\mathbf{2 b}(0.29 \mathrm{~g}, 74 \%)$ recrystallised as white needles $\mathrm{mp}$ 120-121 ${ }^{\circ} \mathrm{C}$ (from $\mathrm{Et}_{2} \mathrm{O}$-petroleum ether); $\left(\mathrm{C}_{25} \mathrm{H}_{31} \mathrm{NO}_{3}\right.$ requires $\mathrm{C} 79.30, \mathrm{H}$ 8.04, $\mathrm{N}$ 3.85; found $\mathrm{C} 79.60, \mathrm{H} 8.19$, $\mathrm{N} \mathrm{3.58);} \nu_{\max }(\mathrm{KBr}) / \mathrm{cm}^{-1} 3398,2933,1723,1608,1510,1238$, $829 ; \delta_{\mathrm{H}}\left(300 \mathrm{MHz}, \mathrm{CDCl}_{3}, \mathrm{Me}_{4} \mathrm{Si}\right) 1.19\left(3 \mathrm{H}, \mathrm{s}, \mathrm{CH}_{3}\right), 1.26$ $\left(3 \mathrm{H}, \mathrm{s}, \mathrm{CH}_{3}\right), 1.30-1.50(2 \mathrm{H}, \mathrm{m}, 2 \times \mathrm{CH}) 1.60-1.80(5 \mathrm{H}, \mathrm{m}$, $2 \times \mathrm{CH}_{2}$ and $\left.\mathrm{CH}\right), 2.21(1 \mathrm{H}, \mathrm{dd}, J 12$ and $1.8, \mathrm{CH}), 2.26$ (1H, brd, $J 12, \mathrm{CH}), 2.78-2.84\left(2 \mathrm{H}, \mathrm{m}, \mathrm{CH}_{2}\right), 3.66\left(3 \mathrm{H}, \mathrm{s}, \mathrm{CH}_{3}\right)$, $3.78\left(3 \mathrm{H}, \mathrm{s}, \mathrm{CH}_{3}\right), 5.38(1 \mathrm{H}$, brs, $\mathrm{NH}), 6.59(1 \mathrm{H}, \mathrm{d}, J 2.1$,
$\mathrm{CH}), 6.72(1 \mathrm{H}, \mathrm{dd}, J 8$ and 2.1, CH), $6.83(2 \mathrm{H}, \mathrm{m}, 2 \times \mathrm{CH}), 7.02$ $(2 \mathrm{H}, \mathrm{m}, 2 \times \mathrm{CH}) .7 .09(1 \mathrm{H}, \mathrm{d}, J 8.2, \mathrm{CH}) ; \delta_{\mathrm{C}}(75 \mathrm{MHz}$, $\mathrm{CDCl}_{3}, \mathrm{Me}_{4} \mathrm{Si}$ ) 16.4, 18.5, 21.6, 25.0, 30.1, 36.6 (2C), 38.1, 45.0, 47.6, 51.9, 55.5, 114.1, 114.6 (2C), 115.7, 121.5 (2C), 125.1, $136.0,136.2,141.4,142.3,154.8,179.1 ; \mathrm{m} / z$ (APCI) 392.7 $[\mathrm{M}+\mathrm{H}]^{+}$.

General procedure for triarylamine synthesis. To a mixture of diarylamine $(0.4 \mathrm{mmol})$, trans-4-bromostilbenes $(0.44 \mathrm{mmol})$ and sodium tert-butoxide $(0.48 \mathrm{mmol})$ in dry $o$-xylene $(0.6 \mathrm{~mL})$ in a Schlenk tube under argon atmosphere were added tri-tert-butylphosphine $(0.04 \mathrm{mmol})$ and palladium acetate $(0.01 \mathrm{mmol})$. The mixture was stirred at $120{ }^{\circ} \mathrm{C}$ until the complete consumption of amine (1-2 h) as judged by TLC. The reaction mixture was then cooled to room temperature, taken up in diethyl ether $(5 \mathrm{~mL})$ and washed with brine. The organic phase was dried over anhydrous sodium sulfate, filtered and concentrated under reduced pressure. The residue obtained was purified by silica column chromatography using mixtures of diethyl ether-petroleum ether $(1.5: 3.5$ to $1: 1)$ as eluent.

Methyl 13-[(trans-4-styryl-phenyl)-phenyl]aminodeisopropyldehydroabietate (3). The general method was used with methyl 13-(phenyl)aminodeisopropyldehydroabietate $2 \mathrm{2a} \quad(0.15 \mathrm{~g}$, $0.41 \mathrm{mmol})$ and trans-(4-bromostyryl)benzene $1 \mathrm{a}(0.12 \mathrm{~g}$, $0.45 \mathrm{mmol})$ to afford $3(0.15 \mathrm{~g}, 67 \%)$ as white crystals $\mathrm{mp}$ 175-176 ${ }^{\circ} \mathrm{C}$ (from diethyl ether-methanol); $\left(\mathrm{C}_{38} \mathrm{H}_{39} \mathrm{NO}_{2}\right.$ requires $\mathrm{C} 84.25, \mathrm{H} \mathrm{7.26,} \mathrm{N} 2.59$; found $\mathrm{C} 84.55, \mathrm{H} 7.33$, $\mathrm{N} 2.52) ; \nu_{\max }(\mathrm{KBr}) / \mathrm{cm}^{-1} 3448,2933,1715,1592,1494,1250$, $1174,965,752 ; \delta_{\mathrm{H}}\left(300 \mathrm{MHz}, \mathrm{CDCl}_{3}, \mathrm{Me}_{4} \mathrm{Si}\right) 1.23(3 \mathrm{H}, \mathrm{s}$, $\left.\mathrm{CH}_{3}\right), 1.28\left(3 \mathrm{H}, \mathrm{s}, \mathrm{CH}_{3}\right), 1.34-1.40(1 \mathrm{H}, \mathrm{m}, \mathrm{CH}), 1.43-1.60$ $(1 \mathrm{H}, \mathrm{m}, \mathrm{CH}), 1.64-1.89\left(5 \mathrm{H}, \mathrm{m}, 2 \times \mathrm{CH}_{2}\right.$ and $\left.\mathrm{CH}\right), 2.23$ $(1 \mathrm{H}, \mathrm{dd}, J 13$ and 2.1, CH), $2.27(1 \mathrm{H}$, brd, $J 13 \mathrm{~Hz}, \mathrm{CH})$, 2.75-2.80 (2H, m, CH $), 3.67\left(3 \mathrm{H}, \mathrm{s}, \mathrm{CH}_{3}\right), 6.77(1 \mathrm{H}, \mathrm{d}, J 2.4$ $\mathrm{Hz}, \mathrm{CH}), 6.86(1 \mathrm{H}, \mathrm{dd}, J 8.4$ and $2.4, \mathrm{CH}), 6.95-7.13(9 \mathrm{H}, \mathrm{m}$, $9 \times \mathrm{CH}), 7.20-7.27(2 \mathrm{H}, \mathrm{m}, 2 \times \mathrm{CH}), 7.31-7.38(4 \mathrm{H}, \mathrm{m}$, $4 \times \mathrm{CH}), 7.49(2 \mathrm{H}, \mathrm{d}, J 7.5,2 \times \mathrm{CH}) ; \delta_{\mathrm{C}}\left(75 \mathrm{MHz}, \mathrm{CDCl}_{3}\right.$, $\left.\mathrm{Me}_{4} \mathrm{Si}\right)$ 16.5, 18.6, 21.6, 25.1, 29.9, 36.7, 36.9, 38.0, 44.9, 47.6, $52.0,122.4,122.6,123.2(2 \mathrm{C}), 124.2(2 \mathrm{C}), 124.7,125.1,126.3$ (2C), 126.7, 127.2 (3C), 128.2, 128.6 (2C), 129.2 (2C), 131.0, $136.0,137.7,144.5,144.8,147.5,147.6,179.2 ; \mathrm{m} / z$ (APCI) $541.7[\mathrm{M}+\mathrm{H}]^{+}$.

Methyl 13-[(trans-4-styrylphenyl)-(4-methoxyphenyl)]aminodeisopropyldehydroabietate (4). The general method was used with methyl 13-(4-methoxyphenyl)-aminodeisopropyldehydroabietate $\mathbf{2 b}(0.16 \mathrm{~g}, 0.41 \mathrm{mmol})$ and trans-(4-bromostyryl)benzene 1a $(0.12 \mathrm{~g}, 0.45 \mathrm{mmol})$ to afford $4(0.16 \mathrm{~g}, 69 \%)$ as a white powder mp $104-106{ }^{\circ} \mathrm{C}$ (from diethyl ether-methanol); $\left(\mathrm{C}_{39} \mathrm{H}_{41} \mathrm{NO}_{3}\right.$ requires $\mathrm{C} 81.93, \mathrm{H} 7.23, \mathrm{~N} 2.45$; found $\mathrm{C} 81.83$, $\mathrm{H}$ 7.24, N 2.44); $\nu_{\max }(\mathrm{KBr}) / \mathrm{cm}^{-1} 3448,2926,1723,1594$, $1505,1243,1178,691 ; \delta_{\mathrm{H}}\left(300 \mathrm{MHz}, \mathrm{CDCl}_{3}, \mathrm{Me}_{4} \mathrm{Si}\right) 1.22$ $\left(3 \mathrm{H}, \mathrm{s}, \mathrm{CH}_{3}\right), 1.28\left(3 \mathrm{H}, \mathrm{s}, \mathrm{CH}_{3}\right), 1.33-1.39(1 \mathrm{H}, \mathrm{m}, \mathrm{CH})$, 1.46-1.56 $(1 \mathrm{H}, \mathrm{m}, \mathrm{CH}), 1.64-1.84\left(5 \mathrm{H}, \mathrm{m}, 2 \times \mathrm{CH}_{2}\right.$ and $\mathrm{CH}), 2.22(1 \mathrm{H}, \mathrm{dd}, J 13$ and $1.8 \mathrm{~Hz}, \mathrm{CH}), 2.26(1 \mathrm{H}$, brd, $J 13 \mathrm{~Hz}, \mathrm{CH}), 2.74-2.79\left(2 \mathrm{H}, \mathrm{m}, \mathrm{CH}_{2}\right), 3.67\left(3 \mathrm{H}, \mathrm{s}, \mathrm{CH}_{3}\right), 3.81$ $\left(3 \mathrm{H}, \mathrm{s}, \mathrm{CH}_{3}\right), 6.73(1 \mathrm{H}, \mathrm{d}, J 2.4, \mathrm{CH}), 6.81-6.87(3 \mathrm{H}, \mathrm{m}$, $3 \times \mathrm{CH}), 6.93-7.11(7 \mathrm{H}, \mathrm{m}, 7 \times \mathrm{CH}), 7.19-7.24(1 \mathrm{H}, \mathrm{m}, \mathrm{CH})$, $7.31-7.36(4 \mathrm{H}, \mathrm{m}, 4 \times \mathrm{CH}), 7.48(2 \mathrm{H}, \mathrm{d}, J 7.2,2 \times \mathrm{CH})$ 
$\delta_{\mathrm{C}}\left(75 \mathrm{MHz}, \mathrm{CDCl}_{3}, \mathrm{Me}_{4} \mathrm{Si}\right) 16.5,18.6,21.6,25.1,30.0,36.7$, $36.9,38.0,44.9,47.6,52.0,55.5,114.7$ (2C), 121.4, $121.8(2 \mathrm{C})$, 123.6, 125.0, 126.2 (2C), 126.3 (2C), 127.2 (2C), 127.3 (3C), $128.4,128.6$ (2C), 130.1, 135.9, 137.8, 140.5, 144.1, 144.8, 148.0, 156.1, 179.2; $\mathrm{m} / \mathrm{z}$ (APCI) $572.0[\mathrm{M}+\mathrm{H}]^{+}$.

Methyl 13-\{[trans-4-(4-methoxystyryl)phenyl]-phenyl\}aminodeisopropyldehydroabietate (5). The general method was used with methyl 13-(phenyl)aminodeisopropyldehydroabietate 2a $(0.12 \mathrm{~g}, 0.33 \mathrm{mmol})$ and trans-4-(4-bromostyryl)methoxybenzene $1 \mathbf{b}(0.11 \mathrm{~g}, 0.40 \mathrm{mmol})$ to afford $\mathbf{5}(0.12 \mathrm{~g}, 63 \%)$ as white microcrystals mp $120-123{ }^{\circ} \mathrm{C}$ (from $\mathrm{Et}_{2} \mathrm{O}$-petroleum ether); $\left(\mathrm{C}_{39} \mathrm{H}_{41} \mathrm{NO}_{3}\right.$ requires $\mathrm{C} 81.93, \mathrm{H} 7.23, \mathrm{~N} 2.45$; found $\mathrm{C}$ $81.70, \mathrm{H} 7.40, \mathrm{~N} 2.47) ; \nu_{\max }(\mathrm{KBr}) / \mathrm{cm}^{-1} 3448,2930,1720$, $1511,1493,1250,1174,1037,697 ; \delta_{\mathrm{H}}\left(300 \mathrm{MHz}, \mathrm{CDCl}_{3}\right.$, $\left.\mathrm{Me}_{4} \mathrm{Si}\right) 1.22\left(3 \mathrm{H}, \mathrm{s}, \mathrm{CH}_{3}\right), 1.28\left(3 \mathrm{H}, \mathrm{s}, \mathrm{CH}_{3}\right), 1.34-1.40(1 \mathrm{H}, \mathrm{m}$, $\mathrm{CH}), 1.47-1.54(1 \mathrm{H}, \mathrm{m}, \mathrm{CH}), 1.64-1.84\left(5 \mathrm{H}, \mathrm{m}, 2 \times \mathrm{CH}_{2}\right.$ and $\mathrm{CH}), 2.22(1 \mathrm{H}, \mathrm{dd}, J=12$ and $2.1, \mathrm{CH}), 2.27(1 \mathrm{H}$, brd, $J$ 13, CH), 2.74-2.80 (2H, m, $\left.\mathrm{CH}_{2}\right), 3.67\left(3 \mathrm{H}, \mathrm{s}, \mathrm{CH}_{3}\right), 3.82$ $\left(3 \mathrm{H}, \mathrm{s}, \mathrm{CH}_{3}\right), 6.76(1 \mathrm{H}, \mathrm{d}, J 2.4), 6.83-6.95(5 \mathrm{H}, \mathrm{m}, 5 \times \mathrm{CH})$, 6.96-7.05 (3H, m, $3 \times \mathrm{CH}), 7.06-7.14(3 \mathrm{H}, \mathrm{t}, J 8.7,3 \times \mathrm{CH})$, 7.2-7.27 (2H, m, $2 \times \mathrm{CH}), 7.34,(2 \mathrm{H}, \mathrm{d}, J 8.7,2 \times \mathrm{CH}), 7.42$, $(2 \mathrm{H}, \mathrm{d}, J 8.7,2 \times \mathrm{CH}) ; \delta_{\mathrm{C}}\left(75 \mathrm{MHz}, \mathrm{CDCl}_{3}, \mathrm{Me}_{4} \mathrm{Si}\right) 16.5,18.6$, 21.6, 25.1, 29.9, 36.7, 36.9, 38.0, 44.9, 47.6, 52.0, 55.3, 114.1 (2C), 122.3, 122.5, 123.5 (2C), 124.1 (2C), 124.5, 125.1, 126.2, $126.4,127.0$ (2C), 127.4 (2C), 129.1 (2C), 130.5, 131.5, $136.0,144.6,144.7,147.1,147.7,159.0,179.1 ; \mathrm{m} / z$ (APCI) $572.1[\mathrm{M}+\mathrm{H}]^{+}$.

Methyl 13-\{[trans-4-(4-methoxystyryl)phenyl]-(4-methoxyphenyl)]\}aminodeisopropyl-dehydroabietate (6). The general method was used with methyl 13-(4-methoxyphenyl)aminodeisopropyldehydroabietate $\mathbf{2 b}(0.11 \mathrm{~g}, 0.25 \mathrm{mmol})$ and trans4-(4-bromostyryl)-methoxybenzene $\mathbf{1 b}(0.08 \mathrm{~g}, 0.28 \mathrm{mmol})$ to afford $6(0.10 \mathrm{~g}, 77 \%)$ as a white solid $\mathrm{mp} 98-101{ }^{\circ} \mathrm{C}$ (from $\mathrm{Et}_{2} \mathrm{O}$-petroleum ether); $\left(\mathrm{C}_{40} \mathrm{H}_{43} \mathrm{NO}_{4}\right.$ : calculated $\mathrm{C} 79.84, \mathrm{H}$ 7.20, N 2.33; found C 79.90, H 7.27, N 2.33); $\nu_{\max }(\mathrm{KBr}) / \mathrm{cm}^{-1}$ $3448,2930,1723,1605,1509,1244,1175,1036,830 ; \delta_{\mathrm{H}}$ (300 MHz, $\left.\mathrm{CDCl}_{3}, \mathrm{Me}_{4} \mathrm{Si}\right) 1.22\left(3 \mathrm{H}, \mathrm{s}, \mathrm{CH}_{3}\right), 1.27(3 \mathrm{H}, \mathrm{s}$, $\left.\mathrm{CH}_{3}\right), 1.33-1.39(1 \mathrm{H}, \mathrm{m}, \mathrm{CH}), 1.47-1.54(1 \mathrm{H}, \mathrm{m}, \mathrm{CH})$, $1.66-1.83\left(5 \mathrm{H}, \mathrm{m}, 2 \times \mathrm{CH}_{2}\right.$ and $\left.\mathrm{CH}\right), 2.22(1 \mathrm{H}, \mathrm{dd}, J 12$ and 2.1, CH), $2.27(1 \mathrm{H}$, brd, $J 13, \mathrm{CH}), 2.72-2.80\left(2 \mathrm{H}, \mathrm{m}, \mathrm{CH}_{2}\right)$, $3.67\left(3 \mathrm{H}, \mathrm{s}, \mathrm{CH}_{3}\right), 3.80\left(3 \mathrm{H}, \mathrm{s}, \mathrm{CH}_{3}\right), 3.82\left(3 \mathrm{H}, \mathrm{s}, \mathrm{CH}_{3}\right), 6.72$ $(1 \mathrm{H}, \mathrm{d}, J 2.4, \mathrm{CH}), 6.79-7.00(11 \mathrm{H}, \mathrm{m}, \mathrm{CH}), 6.99-7-15(2 \mathrm{H}, \mathrm{m}$, $\mathrm{CH}), 7.31,(2 \mathrm{H}, \mathrm{d}, J 8.7, \mathrm{CH}), 7.42,(2 \mathrm{H}, \mathrm{d}, J 8.7, \mathrm{CH}) ; \delta_{\mathrm{C}}$ (75 $\mathrm{MHz}, \mathrm{CDCl}_{3}, \mathrm{Me}_{4} \mathrm{Si}$ ) 16.5, 18.6, 21.6, 25.1, 29.9, 36.7, 36.9, 38.0, 44.9, 47.6, 51.9, 55.3, 55.5, 114.1 (2C), 114.7 (2C), $121.2,122.0$ (2C), 123.4, 125.0, 125.9, 126.3, 126.9 (2C), 127.2 (2C), $127.4(2 \mathrm{C}), 130.6,135.9,140.6,143.9,144.9,147.6,156.0$, $158.9,170.1,179.2 ; m / z$ (APCI) $602.4[\mathrm{M}+\mathrm{H}]^{+}$.

Methyl 13-\{[trans-4-(4-dimethylaminostyryl)phenyl]-phenyl\}aminodeisopropyl-dehydroabietate (7). The general method was used with methyl 13-(phenyl)amino-deisopropyldehydroabietate 2a (0.15 g, $0.41 \mathrm{mmol})$ and trans-4-(4-bromostyryl)dimethylaniline $1 \mathrm{c}(0.14 \mathrm{~g}, 0.45 \mathrm{mmol})$ to give $7(0.14 \mathrm{~g}, 60 \%)$ as a yellow powder $\mathrm{mp} 174-176{ }^{\circ} \mathrm{C}$ (from dichloromethanen-hexane); $\left(\mathrm{C}_{40} \mathrm{H}_{44} \mathrm{~N}_{2} \mathrm{O}_{2}\right.$ requires $\mathrm{C} \quad 82.15, \quad \mathrm{H} \quad 7.58$, $\mathrm{N}$ 4.79; found $\mathrm{C} 82.24, \mathrm{H} 7.59, \mathrm{~N} 4.78) ; \nu_{\max }(\mathrm{KBr}) / \mathrm{cm}^{-1}$ $3448,2932,1718,1607,1524,1495,1250,1123,696 ; \delta_{\mathrm{H}}$
(300 MHz, $\left.\mathrm{CDCl}_{3}, \mathrm{Me}_{4} \mathrm{Si}\right) 1.22\left(3 \mathrm{H}, \mathrm{s}, \mathrm{CH}_{3}\right), 1.28\left(3 \mathrm{H}, \mathrm{s}, \mathrm{CH}_{3}\right)$, $1.35-1.40$ (1H, m, CH), 1.42-1.56 (1H, m, CH), 1.64-1.85 $(5 \mathrm{H}$, $\mathrm{m}, 2 \times \mathrm{CH}_{2}$ and $\left.\mathrm{CH}\right), 2.23(1 \mathrm{H}, \mathrm{d}, J 13, \mathrm{CH}), 2.27(1 \mathrm{H}$, brd, $J$ 12, $\mathrm{CH}), 2.74-2.78\left(2 \mathrm{H}, \mathrm{m}, \mathrm{CH}_{2}\right), 2.98\left(6 \mathrm{H}, \mathrm{s}, 2 \times \mathrm{CH}_{3}\right), 3.67$ $\left(3 \mathrm{H}, \mathrm{s}, \mathrm{CH}_{3}\right), 6.71(2 \mathrm{H}, \mathrm{d}, J 8.4,2 \times \mathrm{CH}) 6.76(1 \mathrm{H}, \mathrm{d}, J 2.4$, $\mathrm{CH}), 6.83-6.91(3 \mathrm{H}, \mathrm{m}, 3 \times \mathrm{CH}), 6.95-7.12(6 \mathrm{H}, \mathrm{m}, 6 \times \mathrm{CH})$, $7.23(2 \mathrm{H}, \mathrm{t}, J 7.2,2 \times \mathrm{CH}), 7.32-7.40(4 \mathrm{H}, \mathrm{m}, 4 \times \mathrm{CH}) ; \delta_{\mathrm{C}}$ (75 $\left.\mathrm{MHz}, \mathrm{CDCl}_{3}, \mathrm{Me}_{4} \mathrm{Si}\right)$ 16.5, 18.6, 21.6, 25.1, 29.9, 36.7, 36.9, 38.0, 40.5, 44.9, 47.6, 52.0, 112.5 (2C), 122.1, $122.3(2 \mathrm{C})$, 123.8 (2C), 123.9, 124.0, 124.4, 125.0, 126.2, 126.7 (2C), 127.1, 127.3 (2C), 129.1 (2C), 132.3, 136.0, 144.5, 144.7, 146.6, 147.8, 149.9, 179.1; $m / z$ (APCI) $585.2[\mathrm{M}+\mathrm{H}]^{+}$.

Methyl 13-\{[trans-4-(4-nitrostyryl)phenyl]-phenyl\}aminodeisopropyldehydroabietate (8). The general method was used with methyl 13-(phenyl)aminodeisopropyldehydroabietate 2a (0.15 g, $0.41 \mathrm{mmol})$ and trans-4-(4-bromostyryl)-nitrobenzene 1d $(0.14 \mathrm{~g}, 0.45 \mathrm{mmol})$ to afford $8(0.18 \mathrm{~g}, 75 \%)$ as orange plates $\mathrm{mp} 186-188{ }^{\circ} \mathrm{C}$ (from dichloromethane- $n$-hexane); $\left(\mathrm{C}_{38} \mathrm{H}_{38} \mathrm{~N}_{2} \mathrm{O}_{4}\right.$ : calculated $\mathrm{C} 77.79, \mathrm{H} 6.53, \mathrm{~N} 4.77$; found $\mathrm{C}$ 77.50, H 6.52, N 4.68); $\nu_{\max }(\mathrm{KBr}) / \mathrm{cm}^{-1} 3448,2925,1728$, $1584,1509,1489,1337,1108,698 ; \delta_{\mathrm{H}}\left(300 \mathrm{MHz}, \mathrm{CDCl}_{3}\right.$, $\left.\mathrm{Me}_{4} \mathrm{Si}\right) 1.23\left(3 \mathrm{H}, \mathrm{s}, \mathrm{CH}_{3}\right), 1.28\left(3 \mathrm{H}, \mathrm{s}, \mathrm{CH}_{3}\right), 1.36-1.41(1 \mathrm{H}, \mathrm{m}$, $\mathrm{CH}), 1.45-1.58(1 \mathrm{H}, \mathrm{m}, \mathrm{CH}), 1.65-1.85\left(5 \mathrm{H}, \mathrm{m}, 2 \times \mathrm{CH}_{2}\right.$ and $\mathrm{CH}), 2.23(1 \mathrm{H}, \mathrm{dd}, J 12$ and $2.1 \mathrm{~Hz}, \mathrm{CH}), 2.28(1 \mathrm{H}, \mathrm{brd}, J=$ 15, CH), 2.76-2.81 (2H, m, $\left.\mathrm{CH}_{2}\right), 3.68\left(3 \mathrm{H}, \mathrm{s}, \mathrm{CH}_{3}\right), 6.78$ $(1 \mathrm{H}, \mathrm{d}, J 2.4, \mathrm{CH}), 6.87(1 \mathrm{H}, \mathrm{dd}, J 9$ and $2.4, \mathrm{CH}), 7.01-7.18$ $(8 \mathrm{H}, \mathrm{m}, 8 \times \mathrm{CH}), 7.23-7.30(2 \mathrm{H}, \mathrm{m}, 2 \times \mathrm{CH}), 7.38(2 \mathrm{H}, \mathrm{d}$, $J 8.7,2 \times \mathrm{CH}), 7.58(2 \mathrm{H}, \mathrm{d}, J 8.7,2 \times \mathrm{CH}), 8.19(2 \mathrm{H}, \mathrm{d}, J 8.7$, $2 \times \mathrm{CH}) ; \delta_{\mathrm{C}}\left(75 \mathrm{MHz}, \mathrm{CDCl}_{3}, \mathrm{Me}_{4} \mathrm{Si}\right) 16.5,18.5,21.6,25.1$, 29.9, 36.7, 37.0, 37.9, 44.9, 47.6, 52.0, 122.2 (2C), 122.8, 123.2, 123.8, 124.2 (2C), 124.8 (2C), 125.2, $125.3,126.4$ (2C), 127.9 (2C), 129.2, 129.3 (2C), 133.0, 136.2, 144.1, 144.4, 145.4, 146.1, 147.2, 148.7, 179.1; $m / z$ (APCI) $587.1[\mathrm{M}+\mathrm{H}]^{+}$.

Methyl 13-[(4-nitrophenyl)-phenyl]aminodeisopropyldehydroabietate (9). The general method was used with methyl 13-(phenyl)aminodeisopropyldehydroabietate $\quad \mathbf{2 a} \quad(0.15 \mathrm{~g}$, $0.41 \mathrm{mmol})$ and 1-bromo-4-nitrobenzene $(0.091 \mathrm{~g}, 0.45 \mathrm{mmol})$ to afford 9 as a yellow foam $(115 \mathrm{mg}, 58 \%) ;\left(\mathrm{C}_{30} \mathrm{H}_{32} \mathrm{~N}_{2} \mathrm{O}_{4}\right.$ requires $\mathrm{C}, 74.36, \mathrm{H} 6.66, \mathrm{~N} 5.78$; found $\mathrm{C} 74.32, \mathrm{H} 6.65$, $\mathrm{N} \mathrm{5.79}) ; \nu_{\max }(\mathrm{KBr}) / \mathrm{cm}^{-1} 3448,2931,1724,1508,1493,1242$, 696; $\delta_{\mathrm{H}}\left(300 \mathrm{MHz}, \mathrm{CDCl}_{3}, \mathrm{Me}_{4} \mathrm{Si}\right) 1.24\left(3 \mathrm{H}, \mathrm{s}, \mathrm{CH}_{3}\right), 1.29$ $\left(3 \mathrm{H}, \mathrm{s}, \mathrm{CH}_{3}\right), 1.31-1.39(1 \mathrm{H}, \mathrm{m}, \mathrm{CH}), 1.44-1.56(1 \mathrm{H}, \mathrm{m}, \mathrm{CH})$, 1.63-1.83 (5H, m, $\mathrm{CH}_{2}$ and $\left.\mathrm{CH}\right), 2.22(1 \mathrm{H}, \mathrm{dd}, J 12$ and 2.1, $\mathrm{CH}), 2.29$ (1H, brd, $J 12, \mathrm{CH}), 2.80-2.88\left(2 \mathrm{H}, \mathrm{m}, \mathrm{CH}_{2}\right), 3.68$ $\left(3 \mathrm{H}, \mathrm{s}, \mathrm{CH}_{3}\right), 6.83-6.94(4 \mathrm{H}, \mathrm{m}, \mathrm{CH}), 67.16-7.26(4 \mathrm{H}, \mathrm{m}, \mathrm{CH})$, 7.33-7.38 (2H, t, CH), 8.00-8.03 (2H, d, J 9, CH); $\delta_{\mathrm{C}}$ (75 $\mathrm{MHz}, \mathrm{CDCl}_{3}, \mathrm{Me}_{4} \mathrm{Si}$ ) 16.5, 18.5, 21.5, 25.1, 29.8, 36.7, 37.2, 37.9, 45.0, 47.6, 52.0, 117.6 (2C), 124.0, 125.4 (2C), 125.6, 125.8 (3C), 126.5, 126.7, 129.8 (2C), 137.0, 139.7, 142.6, 145.6, $147.5,153.7,179.0 ; \mathrm{m} / z$ (EI) $484\left(\mathrm{M}^{+}, 100 \%\right), 485(30)$, $386(5)$.

\section{Acknowledgements}

We thank POCI, FCT and FEDER for financial support under contract POCI/QUI/58291/2004. SMF gratefully acknowledges the award of a postdoctoral fellowship from the FCT. We are also grateful to a referee for valuable 
comments on the application of the Strickler-Berg procedure. JP gratefully acknowledges a $\mathrm{PhD}$ grant (BD/18876/2004) from the FCT.

\section{References}

1 For reviews see: Y. Shirota, J. Mater. Chem., 2000, 10, 1; U. Mitschke and P. Bauerle, J. Mater. Chem., 2000, 10, 1471; M. Thelakkat, Macromol. Mater. Eng., 2002, 287, 442; Y. Shirota, J. Mater. Chem., 2005, 15, 75; K. R. Justin Thomas, J. T. Lian, C.-M. Tsai and H.-C. Lin, Tetrahedron, 2006, 62, 3517.

2 M. Stolka, J. F. Yanus and D. M. Pai, J. Phys. Chem., 1984, 88, 4707; C. W. Tang and S. A. VanSlyke, Appl. Phys. Lett., 1987, 51, 913; J. H. Burroughes, D. D. C. Bradley, A. R. Brown, R. N. Marks, K. Mackay, R. H. Friend, P. L. Burns and A. B. Holmes, Nature, 1990, 347, 539; H. Zhao, C. Tanjutco and S. Thayumanavan, Tetrahedron Lett., 2001, 42, 4421.

3 T. Miteva, A. Meisel, W. Knoll, H. G. Nothofer, U. Scherf, D. C. Müller, K. Meerholz, A. Yasuda and D. Neher, Adv. Mater., $2001,13,565$.

4 H. Xiao, B. Leng and H. Tian, Polymer, 2005, 46, 5707.

5 H. Tanaka, S. Tokito, Y. Taga and A. Okada, Chem. Commun., 1996, 2175.

6 G. E. Jabbour, S. E. Shaheen, M. M. Morrell, J. D. Anderson, P. Lee, S. Thayumanavan, S. Barlow, E. Bellman, R. H. Grubbs, B. Kippelen, S. Marder, N. R. Armstrong and N. Peyghambarian, IEEE J. Quantum Electron., 2000, 36, 12.

7 J. P. Chen, H. Tanabe, X.-C. Li, T. Thoms, Y. Okamura and K. Ueno, Synth. Met., 2005, 132, 173.

8 E. M. Han, L. M. Do, Y. Niidome and M. Fujihira, Chem. Lett., 1994, 969.

9 H. D. Burrows, R. A. E. Castro, M. A. Esteves, B. Gigante, M. L. P. Leitão and A. C. Pauleta, Mater. Sci. Forum, 2006, 514-516, 8

10 J. Morgado, L. Alcácer, M. A. Esteves, N. Pires and B. Gigante, Thin Solid Films, 2007, 515, 7697.

11 H. D. Burrows, S. M. Fonseca, B. Gigante, M. A. Esteves and A. M. Guerreiro, J. Fluoresc., 2006, 16, 227.
12 J.-S. Yang, S.-Y. Chiou and K.-L. Liau, J. Am. Chem. Soc., 2002, 124, 2518; H.-C. Li, Y.-P. Lin, P.-T. Chou, Y.-M. Cheng and R.-S. Liu, Adv. Funct. Mater., 2007, 17, 520.

13 R. E. Di Paolo, B. Gigante, M. A. Esteves, N. Pires, C. Santos, M. H. Lameiro, J. Seixas de Melo, H. D. Burrows and A. L. Maçanita, ChemPhysChem, 2008, 9, 2214.

14 P. N. Prasad and D. J. Williams, Introduction to Nonlinear Optical Effects in Molecules and Polymers, Wiley-Interscience, New York, 1990.

15 T. Yamamoto, M. Nishiyama and Y. Koie, Tetrahedron Lett., 1998, 39, 2367.

16 M.A. Esteves, N. Narender, M. J. Marcelo-Curto and B. Gigante, J. Nat. Prod., 2001, 64, 761 .

17 See, for example: E. M. Kosower, Acc. Chem. Res., 1982, 15, 2259.

18 H. D. Burrows, N. Chattopadhyay, M. A. Esteves, M. Fernandes and B. Gigante, J. Fluoresc., 2007, 17, 701.

19 S. J. Strickler and R. A. Berg, J. Chem. Phys., 1962, 37, 814.

20 R. V. Bensasson, E. J. Land and T. G. Truscott, Excited States and Free Radicals in Biology and Medicine, Oxford University Press, Oxford, 1993, pp. 90.

21 N. J. Turro, Modern Molecular Photochemistry, University Science Books, Saulsalito, California, 1991, pp. 170-172.

22 R. S. Becker, J. Seixas de Melo, A. L. Maçanita and F. Elisei, J. Phys. Chem., 1996, 100, 18683.

23 J. Seixas de Melo, H. D. Burrows, M. Svensson, M. R. Andersson and A. P. Monkman, J. Chem. Phys., 2003, 118, 1550.

24 F. J. P. Caetano, J. M. N. A. Fareleira, C. M. B. P. Oliveira and W. A. Wakeham, J. Chem. Eng. Data, 2005, 50, 1875.

25 D. D. Perrin and W. L. F. Armarego, Purification of Laboratory Chemicals, Pergamon, Oxford, 3rd edn, 1988.

$26 \mathrm{~J}$. W. Bridges, in Standards in Fluorescence Spectrometry, ed. J. N. Miller, Chapman and Hall, London, 1981, ch. 8.

27 J. Seixas de Melo, L. M. Silva and M. Kuroda, J. Chem. Phys., $2001, \mathbf{1 1 5}, 5625$.

28 G. Striker, V. Subramanian, C. A. M. Seidel and A. Volkmer, J. Phys. Chem. B, 1999, 103, 8612.

29 J. Yamamoto, A. Uchikawa, A. Kawato, A. Shibata, T. Mizutani and R. Nakashima, J. Chem. Soc. Jpn., Chem. Ind. Chem., 1992, 9, 874.

30 D. De Vos, J. Spierenburg and J. Wolters, Recl. Trav. Chim. Pays-Bas, 1972, 91, 1465. 